\title{
Antimicrobial activity of species Zingiber officinale Roscoe and Alpinia purpurata (Vieill.) K. Schum. (Zingiberaceae) - Review
}

\section{Atividade antimicrobiana das espécies Zingiber officinale Roscoe e Alpinia purpurata (Vieill.) K. Schum. (Zingiberaceae) - Revisão}

\author{
Andréia Assunção Soares ${ }^{1 *}$; Ezilda Jacomassi²; Rosana da Mata ${ }^{3}$; \\ Karoline Franciani Cardoso Lopes ${ }^{4}$; Jessé Lahos Borges ${ }^{4}$; \\ Ulisses de Pádua Pereira5; Ricardo de Melo Germano ${ }^{6}$; Luciana Kazue Otutumi ${ }^{7}$; \\ Lisiane de Almeida Martins ${ }^{7}$; Daniela Dib Gonçalves ${ }^{7}$
}

\begin{abstract}
The functionality of nutraceutical foods is attributed to their bioactive compounds. These compounds are widely produced by plants, such as phenolic compounds, which have antioxidant activity and/or antimicrobial activity, acting against damage to macromolecules such as lipids, proteins, and nucleic acids. Secondary plant metabolites, including classes such as phenolic compounds, alkaloids, and terpenoids, have a wide variety of biological activities with medicinal potential. These secondary metabolites are considered bioactive compounds. The Zingiberaceae family received special attention for their large bioactive compound production. Such compounds are useful in foods as herbs, spices, flavorings, and seasonings and in the pharmaceutical and cosmetic industries as antioxidants and antimicrobials. Gingers are recognized as safe by the American Food and Drug Administration (FDA), resulting in no side effects when consumed in moderate amounts. Recent studies show that, in addition to rhizomes, the leaves and flowers of some ginger species have antioxidant activity and consequent medicinal potential. Studies have demonstrated that in vitro and in vivo research is needed to evaluate the efficacy of ginger extracts and understand their role in the modulation of biological and molecular pathways, thus enabling the development of new therapeutic strategies. Thereby, the present work aims to provide a bibliographic review on the antimicrobial activity of Zingiber officinale Roscoe and Alpinia purpurata (Vieill.) K. Schum. (Zingiberaceae), popularly known as ginger and red ginger respectively, and their potential use in the One Health initiative.
\end{abstract}

Key words: Antimicrobial Agents. Pathogenic Bacteria. Bioactive Compounds. Spices. Medicinal Potential.

\footnotetext{
1 Bióloga, Bolsista PNPD/CAPES, Programa de Pós-Graduação em Ciência Animal com Ênfase em Produtos Bioativos, Universidade Paranaense, UNIPAR, Umuarama, PR, Brasil. E-mail: andasoares7@gmail.com

2 Bióloga, Mestrado Profissional de Plantas Medicinais e Fitoterápicos na Atenção Básica, UNIPAR, Umuarama, PR, Brasil. E-mail: ezilda@prof.unipar.br

3 Farmacêutica, Mestrado Profissional de Plantas Medicinais e Fitoterápicos na Atenção Básica, UNIPAR, Umuarama, PR, Brasil. E-mail: rosana.mtt@hotmail.com

${ }^{4}$ Discentes de Doutorando, Programa de Pós-Graduação em Ciência Animal com Ênfase em Produtos Bioativos, UNIPAR, Umuarama, PR, Brasil.E-mail: karol_.lopes@hotmail.com; lahos@outlook.com

5 Médico Veterinário, Programa de Pós-graduação em Ciência Animal, UEL, Londrina-PR, Brasil. E-mail: upaduapereira@uel.br

6 Biólogo, Programa de Pós-Graduação em Ciência Animal com Ênfase em Produtos Bioativos, UNIPAR, Umuarama, PR, Brasil. E-mail: germano@prof.unipar.br

7 Médicas Veterinárias, Programa de Pós-Graduação em Ciência Animal com Ênfase em Produtos Bioativos, UNIPAR, Umuarama, PR, Brasil. E-mail: otutumi@prof.unipar.br; lisiane.almeida.martins@gmail.com; danieladib@prof.unipar.br

* Author for correpondence
} 


\section{Resumo}

A funcionalidade dos alimentos nutracêuticos é atribuída aos seus compostos bioativos. Estes compostos são amplamente produzidos pelos vegetais, tais como os compostos fenólicos, que possuem atividade antioxidante e/ou atividade antimicrobiana entre outras, agindo contra danos em macromoléculas como lipídeos, proteínas e ácidos nucléicos. Os metabólitos secundários das plantas, incluindo algumas classes como compostos fenólicos, alcaloides e terpenóides, possuem uma ampla variedade de atividades biológicas com potencial medicinal. Esses metabólitos secundários são considerados compostos bioativos. A família Zingiberaceae tem recebido atenção especial, por produzir muitos compostos bioativos que são úteis em alimentos como ervas e especiarias; aromatizantes e temperos; nas indústrias farmacêutica e cosmética como agentes antioxidantes e antimicrobianos. Os gengibres são reconhecidos como seguros pela American Food and Drug Administration (FDA) e não possuem efeitos colaterais quando consumidos em quantidades moderadas. Estudos recentes demonstram que além dos rizomas, as folhas e flores de algumas espécies de gengibres possuem atividade antioxidante e consequentemente um potencial medicinal. Estudos demonstram que são necessárias pesquisas in vitro e in vivo para avaliar a eficácia dos extratos do gengibre e compreender o seu papel na modulação das vias biológicas e moleculares, possibilitando assim, novas estratégias terapêuticas. Dessa forma, o presente trabalho tem como objetivo, uma revisão bibliográfica sobre a atividade antimicrobiana de Zingiber officinale Roscoe e Alpinia purpurata (Vieill.) K. Schum. (Zingiberaceae), conhecidos popularmente como gengibre e gengibre-vermelho respectivamente e seu uso na Saúde Única.

Palavras-chave: Agentes antimicrobianos. Bactérias Patogênicas. Compostos bioativos. Especiarias. Potencial medicinal.

\section{Introduction}

Functional or nutraceutical foods are those that, in addition to performing basic nutritional functions, function as part of the usual diet when ingested. These foods also produce metabolic, physiological, and health benefits, including disease prevention and treatment, and is also safe for use without medical supervision. The functionality of nutraceutical foods is attributed to their bioactive compounds. These compounds are widely produced by plants, such as phenolic compounds, which have antioxidant and / or antimicrobial activities that inhibit damage to macromolecules such as lipids, proteins, and nucleic acids (PERALTA et al., 2008; SOARES, 2002; SOARES et al., 2013). Several plants and spices are well known for their antioxidant and antimicrobial effects, where essential oils and extracts contain a large quantity of bioactive compounds, such as phenolic compounds (MAJHENIC et al., 2007; SAHOO et al., 2014).

Secondary plant metabolites, including some classes of phenolic compounds, alkaloids, and terpenoids, have a wide variety of biological activities with medicinal potential. These secondary metabolites are considered bioactive compounds (GONÇALVES et al., 2015; HALLIWELL et al., 1995; HAMINIUK et al., 2011, 2012; TAIZ; ZEIGER, 2002; VORAVUTHIKUNCHAI, 2007). The Zingiberaceae family has received special attention of many bioactive compounds that are useful in foods like herbs, spices, flavorings, and seasonings and in the pharmaceutical and cosmetic industries as antioxidants and antimicrobials agents (SHARIFI-RAD et al., 2017; CHAN; WONG, 2015; CHEN et al., 2008).

Among the Zingiberaceae species, popular gingers, that are widely cultivated in tropical countries, stand out for their uses in cooking as spices as well as their medicinal use. There are several types of gingers, and recent studies report the medicinal properties such as, antioxidant activity, antimicrobial, anti-inflammatory, and analgesic effects (ZAINAL-ABIDIN et al., 2017; HASAN et al., 2012; VORAVUTHIKUNCHAI, 2007). This 
information on gingers is of great importance, as it facilitates the production of pharmaceuticals, addressing economic and therapeutic concerns to allow an improvement in the quality of life (GUPTA; SHARMA, 2014).

Gingers are recognized as safe by the American Food and Drug Administration (FDA), and have no side effects when consumed in moderation (AZIZI et al., 2015; SPINELLA, 2001). Recent studies showed that, in addition to the rhizomes, the leaves and flowers of some ginger species have antioxidant effects, and consequently medicinal potential (CHAN et al., 2011). Studies have shown that in vitro and in vivo research is needed to evaluate the efficacy of ginger extracts and to understand their role in the modulation of biological and molecular pathways, thus enabling new therapeutic strategies (BALOUIRI et al., 2016; RAHMANI et al., 2014). Thereby, the present study aims to provide a bibliographic review on the antimicrobial activity of Zingiber officinale Roscoe and Alpinia purpurata (Vieill.) K. Schum. (Zingiberaceae), which are popularly known as ginger and red ginger respectively, and their use in the One Health initiative.

\section{Zingiberaceae: Antimicrobial Activity}

Zingiber officinale Roscoe and Alpinia purpurata (Vieill.) K. Schum.

Vegetables, and their by-products, are used in different ways, especially as food and spices. Spices (dehydrated and/or in natura) are food flavoring agents that may come from roots, seeds, leaves, flowers, stems (rhizomes), or other parts of plants (IORA et al., 2015; RAJSEKHAR et al., 2012; RIBEIRO et al., 2015).

Zingiberaceae belong to the Zingiberales order, is pantropically distributed, and includes about 50 genera and 1100 species. One of the striking features of Zingiberaceae is the occurrence of a rhizomelike stem, which is a type of underground stem that develops horizontally in the soil. Zingiberaceae are usually herbs, terrestrial rhizomatous perennials and rarely epiphytics (ZAINAL-ABIDIN et al., 2017; SOUZA; LORENZI, 2005).

Alpinia purpurata and Zingiber officinale are of great importance for scientific research aiming at understanding the medicinal potential of their bioactive compounds.

Zingiber officinale, popularly known as ginger, is widely cultivated for the use of spices, condiments, and medicinal applications, in which the most utilized part of the plant is the rhizome (KAUSHIK; GOYAL, 2011; RAJSEKHAR et al., 2012; SUHAD et al., 2012). The rhizome contains approximately $1-4 \%$ of the volatile oils that are responsible for the taste, aroma, and medicinal potential unique to ginger. They also have other bioactive compounds, such as gingerol, with pharmacological potential due to antioxidant, anti-inflammatory, analgesic, hypoglycemic, antithrombotic, and antimicrobial effects (SHAREEF et al., 2016; SHARIFI-RAD et al., 2017).

Alpinia purpurata, popularly known as red ginger, is used mainly as an ornamental plant, as the red flowers it produced are very attractive with contain aromatic rhizomes (CHAN; WONG, 2015). The most striking feature of this genus is the beauty of their inflorescences, which is the primary reason for their vast ornamental use and the sale of both seeds and flowers. Alpinia purpurata is known worldwide, and but grows primarily in Brazil. However, A. purpurata has little medicinal use (KOBAYASHI et al., 2007; VICTÓRIO, 2011). Phenolic compounds, among them flavonoids, are present in several Alpinia species and are considered promising potential therapeutic agents for the treatment of cardiovascular diseases (SUBRAMANIAN; SUJA, 2011). 
Antimicrobial activity: Mechanisms of action in bacterial cell wall composition

Plants play an important role in traditional pharmaceuticals employed to treat many diseases. The medicinal value of these plants resides in some chemical substances (bioactive compounds) that produce a beneficial physiological action to the organisms that consume them (GUPTA; SHARMA, 2014). The antimicrobial activity of plant extracts resides in a variety of important and essential components for plant survival. Many plants and spices have antimicrobial activity, likely destabilizing cell walls and membranes to induce cell death (DAVIDSON; PARISH, 2001; TAJKARIMI et al., 2010). This demonstrates that different plant antimicrobials can effectively reduce and/or inhibit pathogenic microorganisms, and thus may become a good alternative to conventional antimicrobials (NEGI, 2012).

An antimicrobial agent is a compound that selectively destroys or inhibits the growth of microorganisms. Antibiotics, antiseptics, and disinfectants are all classified as antimicrobial agents. The effect of an antimicrobial can be bactericidal (when it destroys) and bacteriostatic (when it inhibits growth). The antiseptic quality of medicinal plants and their extracts are well recognized, as studies have shown that the secondary metabolites of these plants have medicinal, pharmaceutical, and cosmetic potential (RACHANA; VENUGOPALAN, 2014).

Infectious diseases represent an important cause of morbidity and mortality in the general population. Pharmaceutical companies have been motivated to develop new antimicrobial drugs, due to the constant emergence of microorganisms resistant to conventional antimicrobials. Bacterial species have a genetic ability to acquire and transmit resistance to the currently used antimicrobial agents. There are frequent reports on the isolation of bacteria that are sensitive to drugs routinely used, which become multi-resistant to other drugs available on the market (SILVA; FERNANDES; JÚNIOR, 2010).
In recent years, there has been great interest in the medicinal potential of plants and spices (VORAVUTHIKUNCHAI, 2007). Bioactive compounds isolated from various parts and species of plants have been identified and have benefited new scientific research in the fields of biochemistry, pharmaceuticals, and medicine with the aim of new alternative medicines (GHOSH; RANGAN, 2013).

The outer layer of gram-negative bacteria may be the primary mechanism underlying antibiotic resistance, as it is selective impermeable (DENYER; MAILLARD, 2002; ROMANIUK; CEGELSKI, 2015; SILHAVY et al., 2010; TEJADA et al., 2013).

The literature highlights different approaches to the biological screening of the products of various ginger species (Alpinia galanga and Z. officinale, among others) and the evaluation of new properties. Many studies have shown that bioactive gingers compounds may be an excellent antimicrobial against various pathogens (VORAVUTHIKUNCHAI, 2007). Ginger has traditionally been employed for antibacterial activity against gram-negative and gram-positive bacteria (BALOUIRI et al., 2016; GUPTA; SHARMA, 2014; SUHAD et al., 2012).

\section{Antimicrobial activity: Extracts of Zingiber} officinale Roscoe.

Extracts of $Z$. officinale rhizomes contain phenolic compounds with high antioxidant activity. The antioxidant compounds are compounds widely used to combat free radicals and mediate oxidative stress in the cell. The total phenolic content in the alcoholic extract of the dried ginger rhizome was $870.1 \mathrm{mg} / \mathrm{g}$. The extract exhibited $90.1 \%$ of DPPH radical scavenging activity (free radical - in vitro assay) with $\mathrm{IC}_{50}$ concentration of $0.64 \mathrm{~g} / \mathrm{mL}$. The antioxidant property of the ginger is extremely significant and can be used as a preventive agent against several diseases (STOILOVA et al., 2007).

The most prevalent compound identified in the rhizome of $Z$. officinale is the phenolic compound 
gingerol (in natura), which can be potentially active and can be converted into compounds such as shogaol and zingerone (dehydrated). These bioactive compounds play an important role in disease prevention, but the mechanism of biological action is still not well understood. Various biological functions are altered by ginger, including antioxidant, anti-inflammatory, and antimicrobial activities (LIU et al., 2017; SHARIFI-RAD et al., 2017; RAHMANI et al., 2014; SUHAD et al., 2012).

The gingerol produced by Z. officinale may be responsible for this antimicrobial activity, as, when in contact with the cell wall, it ruptures the cell wall and consequently inhibits cellular permeability leading to cell damage and death of the microorganism (HASAN et al., 2012; OONMETTA-AREE et al., 2006; POELOENGAN, 2011; RAHMANI et al., 2014; SUHAD et al., 2012).

The antimicrobial activity of extracts (methanol and hexane) from the rhizome of $Z$. officinale is related to the previously mentioned bioactive compounds, which can attack cell wall and cell membrane, affecting permeability and interfering in cellular functions such as electron transportation, nutrients, synthesis of proteins and nucleic acids, and enzymatic activity. Thus, such bioactive compounds may have several invasive targets that may lead to inhibition of microbial growth (HASAN et al., 2012; OONMETTA-AREE et al., 2006; POELOENGAN, 2011).

According to Kaushik and Goyal (2011), the different extracts of the rhizome of $Z$. officinale demonstrated antibacterial activity in a disk diffusion assay with gram-negative and grampositive bacteria. The results demonstrated that organic solvents (ethanol, methanol, ethyl acetate, and hexane) were more effective of antimicrobial activity than the aqueous extract. It was also observed that the antimicrobial activity of ginger extracts was more effective against gram-positive than gram-negative bacteria, probably due to the different composition of the cellular membrane.

The ethanolic extracts of the rhizomes from some species of the Zingiberaceae family were efficient antimicrobial agents against several types of bacteria (Staphylococcus aureus, Escherichia coli, Salmonella typhimurium, Listeria monocytogenes, Enterococcus faecalis, and Mycobacterium smegmatis), which cause diarrhea in humans (UDOMTHANADECH et al., 2015). The antimicrobial activity of a $70 \%$ methanolic extract of $Z$. officinale was efficient against the species Staphylococcus aureus, and displayed the antimicrobial potential of the rhizome of $Z$. officinale against gram-negative bacteria (SILVA; FERNANDES JÚNIOR, 2010). In vitro studies have shown that active constituents of the Z. officinale rhizome inhibited the growth of the intestinal bacteria, which ferments undigested carbohydrates causing flatulence, and this process can be neutralized with ginger extract (GUPTA; SHARMA, 2014; WHITE, 2007).

According to Mostafa et al. (2018), the ethanolic extracts of the rhizomes from $Z$. officinale $(10 \mathrm{mg} /$ $\mathrm{mL}$ ) were efficient antimicrobial agents against strains causing food poisoning such Pseudomonas aeruginosa, Staphylococcus aureus, and Bacillus cereus in a disk diffusion assay. Similar results were obtained by Abdelfadel et al. (2016), with aqueous extracts (cold and hot) of the rhizomes from $Z$. officinale by Liu et al. (2017) with extracts and essential oil from $Z$. officinale rhizomes, and by Hartanti et al. (2017) with essential oil from $Z$. officinale rhizomes.

The methanolic extract of the rhizome of Z. officinale demonstrated efficiency in the antimicrobial activity against gram-positive bacteria isolated from bovine mastitis (POELOENGAN, 2011). The antimicrobial activity of the extract was associated with the bioactive compounds, mainly gingerol, a phenolic compound that acts on the 
cell walls of the bacteria causing cellular damages (HASAN et al., 2012; OONMETTA-AREE et al., 2006; RAHMANI et al., 2014).

Hasan et al. (2012) reported six bioactive compounds by high-performance liquid chromatography (HPLC) of the methanolic and hexanolic extracts of the rhizome from $Z$. officinale. These compounds were associated with the antimicrobial efficiency of extracts in disk diffusion assay against gram-positive and gram-negative bacteria. The extracts were more effective against gram-positive than gram-negative bacteria as reported by Kaushik and Goyal (2011). The higher resistance of gram-negative bacteria could be due to the complexity of the cell wall (ROMANIUK; CEGELSKI, 2015; SILHAVY et al., 2010; TEJADA et al., 2013).

The aqueous extract of the rhizome from $Z$. officinale demonstrated antimicrobial activity in a disk diffusion test against gram-positive and gramnegative bacteria, in which the aqueous extract concentration of $0.4 \mathrm{mg} / \mathrm{mL}$, was more efficient that the conventional antibiotics chloramphenicol and gentamicin (SUHAD et al., 2012). An antimicrobial activity test via disk diffusion, and a determination of the minimum inhibitory concentration (MIC) of the water: ethanol extract $50 \%$ of the rhizome from $Z$. officinale, also showed the beneficial effects associated with the bioactive compounds of the extract (BALOUIRI et al., 2016; ABDALRAHMAN et al., 2013).

According to Kateregga et al. (2013), the grampositive bacterial pathogen Streptococcus pyogenes, which causes pharyngitis, causes $80 \%$ of the cases in children and adults. The disk diffusion assay and the MIC were performed with the ethanolic extract of the Z. officinale rhizome, indicating an efficient inhibition of bacterial growth.

The antimicrobial activity of the glycolytic extracted from the $Z$. officinale rhizome was efficient in four bacterial strains. In each study, extracts were obtained with different solvents, and the extracted compounds varied according to the polarity of the solvent and the extraction method. Considering the variety of possible methods and solvents, it is important to evaluate the safety of the extract being assessed (GONÇALVES et al., 2014). Gupta and Sharma (2014), in addition to reporting in vitro studies with active compounds of the $Z$. officinale rhizome that inhibited the growth of intestinal bacteria, could also demonstrate the inhibition of the growth of species of gram-positive and gramnegative bacteria with ethanolic extract of rhizome from gingers (GUPTA; RAVISHANKAR, 2005).

According to Saad et al. (2014), extracts obtained from the leaves and rhizomes of $Z$. officinale, by percolation, demonstrated antimicrobial activity, though the rhizome extract was more efficient than the leaf extract, indicating a probably difference in the bioactive compounds.

The ethanolic extract of the rhizome of $Z$. officinale was efficient in inhibiting the growth of Streptococcus mutans and Streptococcus sanguinis bacteria. These bacteria are commonly found in the normal flora of the oral cavity of people. Factors responsible for the high antibacterial activity of the Z. officinale extract are not yet fully understood, however, the antibacterial activity of the plant is mainly attributed to the bioactive compounds already identified and reported in previous studies. (ZAINAL-ABIDIN et al., 2017; AZIZI et al., 2015).

Antimicrobial activity: Extracts of Alpinia purpurata (Vieill.) K. Schum.

Phytochemical studies of ginger leaves, especially the genus Alpinia, have shown important compounds with antioxidant activity such as flavonoids and phenolic acids. Extracts of the rhizomes of several species of Alpinia and Zingiber demonstrated antioxidant potential when compared to the antioxidants tocopherol and butylated hydroxytoluene (BHT). The antioxidant compounds 
are secondary metabolites produced by plants against oxidative damage (oxidative stress) caused by free radicals such as reactive oxygen species (ROS). These results demonstrated that most of the studied gingers species have a large amount of phenolic compounds and antioxidant activity in the leaves and rhizomes (CHAN et al., 2011).

Alpinia purpurata, better known for ornamental use, has been assessed for medicinal potential, and various parts of the plant have bioactive compounds with therapeutic efficacy. These bioactive compounds can act as antioxidants, anticancer agents, anti-inflammatory agents, and neuroprotective agents (AL-ENAZI, 2018; GHOSH; RANGAN, 2013). This species is little studied, with only two compounds identified from the rhizome, and five from the leaves, and none from the flowers (CHAN; WONG, 2015).

Kochuthressia et al. (2010) demonstrated the antimicrobial activity of different extracts from the leaves, rhizomes, and roots of the red gingers A. purpurata against six different bacterial species by disk diffusion assay. The ethanolic extract from the rhizome was the most efficient in the inhibition of bacterial growth, and the ethanolic extract of the leaves was considered moderately effective.

The bioactive compounds from A. purpurata leaves extracted with different solvents (ethanol, hexane, and butanol) demonstrated antimicrobial activity against the bacterial species Mycobacterium tuberculosis H37Rv (VILLAFLORES et al., 2010).

According to Raj et al. (2012), the ethyl acetate extract from $A$. purpurata leaves showed antimicrobial activity at doses between 5 and $20 \mathrm{mg} /$ $\mathrm{mL}$. Phytochemical analysis of the extract revealed the presence of many secondary compounds, such as alkaloids, saponins, phenolics, flavonoids, terpenoids and others, and these bioactive compounds are related to antimicrobial activity.

Ethanolic extract of $A$. purpurata rhizome has the highest concentration of phenolics and flavonoids, while extracts with chloroform and aqueous solvent have higher concentrations of alkaloids and tannins, respectively. In relation to the extraction solvents, the antimicrobial activity obeys the following order: ethanol $>$ petroleum ether $>$ chloroform, and in relation to the part of the plant proceeds the sequential order: rhizome $>$ leaves $>$ roots. Little research has been done on the pharmacological properties of leaves and rhizomes from A. purpurata. Therefore, little is known about the phytochemistry of this species when compared to other species of Zingiberaceae (CHAN; WONG, 2015).

The antimicrobial activity against strains of E. coli and Lactobacillus bacteria was evident in extracts of the leaves, rhizomes, and roots of A. purpurata with different solvents. The results showed that leaf and root ethanolic extracts were more efficient at inhibiting bacterial growth. Biochemical studies report bioactive compounds as flavonoids responsible for antimicrobial activity (KONA et al., 2015). The methanolic extracts of leaves, flowers, and rhizomes, as well as the essential oil of several species of Alpinia were efficient in the antioxidant and antimicrobial activities (SAHOO et al., 2014; WONG et al., 2009).

Venkatesh et al. (2014), assessed the biological synthesis of silver nanoparticles using aqueous extract of the whole $A$. purpurata plant in the investigation of the antimicrobial activity. The application of silver nanoparticles in the medical industry prevents wound infection with topical ointments. Nanoparticles are also employed to prevent the emergence of bacteria resistant to antibiotics, with the production of new antimicrobial agents (HUTCHISON, 2008). The results showed that the silver nanoparticles obtained from an aqueous extract of the $A$. purpurata plant were efficient in inhibiting the pathogenic bacteria Streptococcus pyogenes, Staphylococcus aureus, E. coli, and Klebsiella pneumonia. 
According to Al-Enazi (2018) and Table 1 shows different extracts of $Z$. officinale Voravuthikunchai (2007), the members of the and A. purpurata that have antimicrobial activity Zingiberaceae family are widely used as spices in against several species of pathogenic bacteria of cooking, and some are used medicinal. Similar to the $Z$. officinale and A. purpurata species reported in this study. Some of these members include $A$. galanga, Curcuma, Curcuma longa, and Zingiber zerumbet.

medical importance.

The results demonstrated in this review of literature on the species $Z$. officinale and $A$. purpurata provide insight into the medicinal potential of bioactive compounds produced by these

Other species such, as A. galanga, bacteria, mainly as antimicrobial agents. Thus, more C. longa, Boesenbergia pandurata, and C. zedoaria, have also been studied as antimicrobial agents (DAS; RAHMAN, 2012; LIMSUWAN; VORAVUTHIKUNCHAI, 2013; PATTARATANAWADEE et al., 2006; VORAVUTHIKUNCHAI, 2007). biochemical, microbiological, and pharmacological studies are needed to further the understanding of the biological mechanisms of these bioactive compounds and, consequently, new alternative extracts and drugs for the prevention and treatment of disease. 
Table 1. Results of article analyzes related to the antimicrobial activity of the species Zingiber officinale and Alpinia purpurata (Zingiberaceae).

\begin{tabular}{|c|c|c|c|c|c|}
\hline Species & $\begin{array}{l}\text { Part of the } \\
\text { plant }\end{array}$ & $\begin{array}{c}\text { Compost } \\
\text { extract }\end{array}$ & Gram-positive bacteria & Gram-negative bacteria & References \\
\hline \multirow{10}{*}{ 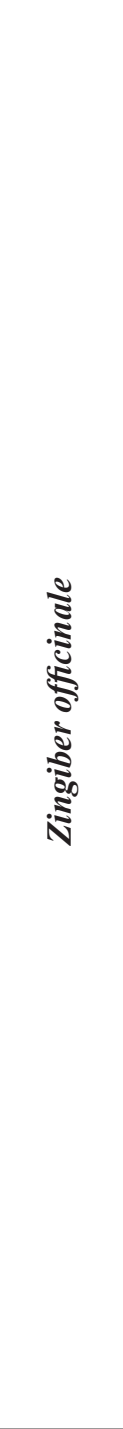 } & rhizome & $\begin{array}{l}\text { aqueous, etha- } \\
\text { nol, methanol, } \\
\text { ethyl acetate, } \\
\text { and hexane }\end{array}$ & $\begin{array}{c}\text { Staphylococcus aureus, } \\
\text { Streptococcus pyogenes, } \\
\text { Bacillus cereus, } \\
\text { Bacillus subtilis }\end{array}$ & $\begin{array}{l}\text { Escherichia coli, } \\
\text { Salmonella typhi }\end{array}$ & $\begin{array}{l}\text { (KAUSHIK; } \\
\text { GOYAL, 2011) }\end{array}$ \\
\hline & rhizome & methanol & $\begin{array}{c}\text { Staphylococcus aureus } \\
\text { Staphylococcus } \\
\text { epidermidis, } \\
\text { Streptococcus agalactiae }\end{array}$ & - & $\begin{array}{l}\text { (POELOEN- } \\
\text { GAN, 2011) }\end{array}$ \\
\hline & rhizome & $\begin{array}{l}\text { methanol and } \\
\text { hexane }\end{array}$ & $\begin{array}{l}\text { Staphylococcus } \\
\text { epidermidis }\end{array}$ & $\begin{array}{c}\text { Klebsiella sp., } \\
\text { Escherichia coli, } \\
\text { Proteus sp., } \\
\text { Enterococcus } \text { sp., } \\
\text { Pseudomonas fluorescens }\end{array}$ & $\begin{array}{l}\text { (HASAN et al., } \\
\text { 2012) }\end{array}$ \\
\hline & rhizome & aqueous & $\begin{array}{l}\text { Staphylococcus aureus, } \\
\text { Streptococcus pyogenes }\end{array}$ & $\begin{array}{l}\text { Klebsiella pneumoniae, } \\
\text { Proteus vulgaris }\end{array}$ & $\begin{array}{l}\text { (SUHAD et al., } \\
\text { 2012) }\end{array}$ \\
\hline & rhizome & $\begin{array}{c}\text { aqueous, } \\
\text { ethanol, } 50 \% \\
\text { water:ethanol }\end{array}$ & $\begin{array}{c}\text { Staphylococcus aureus, } \\
\text { Bacillus subtilis }\end{array}$ & $\begin{array}{c}\text { Escherichia coli, Kleb- } \\
\text { siella, pneumoniae, Pro- } \\
\text { teus vulgaris Pseudomo- } \\
\text { nas aeruginosa, Listeria } \\
\text { monocytogenes }\end{array}$ & $\begin{array}{l}\text { (ABD-AL- } \\
\text { RAHMAN et } \\
\text { al., 2013) }\end{array}$ \\
\hline & rhizome & $\begin{array}{l}\text { ethanol and } \\
\text { hexane }\end{array}$ & Streptococcus pyogenes & - & $\begin{array}{l}\text { (KATEREG- } \\
\text { GAet al., 2013) }\end{array}$ \\
\hline & rhizome & $\begin{array}{l}\text { aqueous glu- } \\
\text { cose }\end{array}$ & $\begin{array}{c}\text { Staphylococcus aureus, } \\
\text { Staphylococcus } \\
\text { epidermidis }\end{array}$ & $\begin{array}{c}\text { Escherichia coli, Pseu- } \\
\text { domonas aeruginosa }\end{array}$ & $\begin{array}{l}\text { (GONÇALVES } \\
\text { et al., 2014) }\end{array}$ \\
\hline & rhizome & ethanol & $\begin{array}{l}\text { Staphylococcus sp., } \\
\text { Streptococcus sp. }\end{array}$ & $\begin{array}{l}\text { Escherichia coli, Proteus } \\
\text { sp., Salmonella sp. }\end{array}$ & $\begin{array}{c}\text { (GUPTA, } \\
\text { SHARMA, } \\
2014)\end{array}$ \\
\hline & $\begin{array}{l}\text { rhizome and } \\
\text { flowers }\end{array}$ & percolation & $\begin{array}{c}\text { Staphylococcus aureus, } \\
\text { Bacillus sp. }\end{array}$ & $\begin{array}{l}\text { Escherichia coli, } \\
\text { Salmonella } \text { sp. }\end{array}$ & $\begin{array}{l}\text { (SAAD et al., } \\
\text { 2014) }\end{array}$ \\
\hline & rhizome & ethanol & $\begin{array}{l}\text { Streptococcus mutans, } \\
\text { Streptococcus sanguinis }\end{array}$ & - & $\begin{array}{l}\text { (AZIZI et al., } \\
\text { 2015) }\end{array}$ \\
\hline \multirow{5}{*}{ 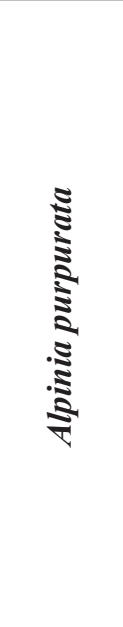 } & $\begin{array}{l}\text { rhizome, } \\
\text { leaves e } \\
\text { flowers }\end{array}$ & $\begin{array}{l}\text { ethanol, } \\
\text { chloroform }\end{array}$ & $\begin{array}{c}\text { Staphylococcus aureus, } \\
\text { Streptococcus faecalis, } \\
\text { Bacillus cereus }\end{array}$ & $\begin{array}{c}\text { Escherichia coli, } \\
\text { Salmonella typhi, } \\
\text { Enterobacter aerogenes }\end{array}$ & $\begin{array}{l}\text { (KOCHUTH- } \\
\text { RESSIA et al., } \\
\text { 2010) }\end{array}$ \\
\hline & leaves & $\begin{array}{c}\text { ethanol hexane, } \\
\text { butanol }\end{array}$ & - & $\begin{array}{l}\text { Mycobacterium } \\
\text { tuberculosis }\end{array}$ & $\begin{array}{l}\text { (VILLA- } \\
\text { FLORES et al., } \\
\text { 2010) }\end{array}$ \\
\hline & leaves & $\begin{array}{l}\text { ethanol, ethyl } \\
\text { acetate }\end{array}$ & $\begin{array}{c}\text { Staphylococcus aureus, } \\
\text { Bacillus cereus, }\end{array}$ & $\begin{array}{c}\text { Escherichia coli, } \\
\text { Klebsiella pneumonia, } \\
\text { Salmonella paratyphi }\end{array}$ & $\begin{array}{l}\text { (RAJ et al., } \\
\text { 2012) }\end{array}$ \\
\hline & rhizome & ethanol & & $\begin{array}{l}\text { Mycobacterium tuber- } \\
\text { culosis }\end{array}$ & $\begin{array}{c}\text { (CHAN; } \\
\text { WONG, 2015) }\end{array}$ \\
\hline & $\begin{array}{l}\text { rhizome, } \\
\text { roots and } \\
\text { leaves }\end{array}$ & $\begin{array}{l}\text { ethanol, hex- } \\
\text { ane, chloro- } \\
\text { form }\end{array}$ & Lactobacillus & Escherichia coli & $\begin{array}{l}\text { (KONA et al., } \\
\text { 2015) }\end{array}$ \\
\hline
\end{tabular}




\section{Conclusions}

The antimicrobial activity of the bioactive compounds produced by the species $Z$. officinale and $A$. purpurata has been previously established and emphasized in this bibliographic review. However, the mechanisms by which these compounds elicit protective effect is not yet fully understood. Therefore, additional research, such as more specific microbiological and clinical trials, is required to establish and understand the efficacy of antimicrobial/therapeutic agents isolated from the $Z$. officinale and A. purpurata species of the Zingiberaceae family.

\section{Acknowledgments}

Paranaense University - UNIPAR (Postgraduate Program in Animal Science with Emphasis on Bioactive Products - Umuarama, Brazil), Coordination for the Improvement of Higher Education Personnel - CAPES and National Counsel of Technological and Scientific Development CNPq.

\section{References}

ABD-ALRAHMAN, S. H.; SALEM-BEKHIT, M. M.; YAKOUT, S. M.; ELHALWAGY, E. A. Chemical composition and antimicrobial activity of various crude extracts of ginger (Zingiber officinale Roscoe). Journal of Pure and Applied Microbiology, Bhopal, v. 7, p. 309316, 2013. Supplement.

ABDELFADEL, M. M.; KHALAF, H. H.; SHAROBA, A. M.; ASSOUS, M. T. M. Effect of extraction methods on antioxidant and antimicrobial activities of some spices and herb extracts. Journal of Food Technology and Nutrition Sciences, Benha, v. 1, n. 1, p. 1-14, 2016.

AL-ENAZI, N. M. Phytochemical screening and biological activities of some species of Alpinia and Convolvulus plants. International Journal of Pharmacology, Alkharj, v. 14, n. 3, p. 301-309, 2018.

AZIZI, A.; AGHAYAN, S.; ZAKER, S.; SHAKERI, M.; ENTEZARI, N.; LAWAF, S. In vitro effect of Zingiber officinale extract on growth of Streptococcus mutans and Streptococcus sanguinis. International Journal of Dentistry, Cairo, v. 2015, p. 1-5, 2015.
BALOUIRI, M.; SADIKI, M.; IBNSOUDA, S. K. Methods for in vitro evaluating antimicrobial activity: Aareview. Journal of Pharmaceutical Analysis, Morocco, v. 6, n. 2, p. 71-79, 2016.

CHAN, E. W. C.; LIM, Y. Y.; WONG, S. K. Antioxidant properties of ginger leaves: an overview. Free Radicals and Antioxidants, Bangalore, v. 1, n. 1, p. 6-16, 2011.

CHAN, E. W. C.; WONG, S. K. Phytochemistry and pharmacology of ornamental gingers, Hedychium coronarium and Alpinia purpurata: a review. Journal of Integrative Medicine, Beijing, v. 13, n. 6, p. 368-379, 2015.

CHEN, I.-N.; CHANG, C.-C.; NG, C.-C.; WANG, C.-Y.; SHYU, Y.-T.; CHANG, T.-L. Antioxidant and antimicrobial activity of Zingiberaceae plants in Taiwan. Plant Foods Human Nutrition, Dordrecht, v. 63, n. 1, p. 15-20, 2008

DAS, K.; RAHMAN, M. A. Analgesic and antimicrobial activities of Curcuma zedoaria. International Journal of Pharmacy and Pharmaceutical Sciences, Madhya Pradesh, v. 4, n. 5, p. 322-328, 2012.

DAVIDSON, P. M.; PARISH, M. E. Methods for testing the efficacy of food antimicrobials. Food Technology, Campinas, v. 43, n. 1, p. 148-155, 2001.

DENYER, S. P.; MAILLARD, J. Y. Cellular impermeability and uptake of biocides and antibiotics in Gram-negative bacteria. Journal of Applied Microbiology Symposium Supplement, Oxford, v. 92, p. 35S-45S, 2002. Supplement.

GHOSH, S.; RANGAN, L. Alpinia: the gold mine of future therapeutics. 3 Biotech, Berlim, v. 3, n. 3, p. 173 183, 2013.

GONÇALVES, G. A.; SÁ-NAKANISHI, A. B.; WENDT, M. M. N.; COMAR, J. F.; BERSANI AMADO, C. A.; BRACHT, A.; PERALTA, R. M. Green tea extract improves the oxidative state of liver and brain in rats with adjuvant-induced arthritis. Food Function, Cambridge, v. 6, n. 8, p. 2701-2711, 2015.

GONÇALVES, G. M. S.; SILVA, G. H. da.; BARROS, P. P.; SREBERNICH, S. M.; TONON, F. R.; FIORE, D. S. Antimicrobial effect and enzymatic activity of extract of Zingiber officinale Roscoe and stability in topical preparations. Revista de Ciências Farmacêuticas Básicas e Aplicada, Araraquara, v. 35, n. 2, p. 205-210, 2014.

GUPTA, S. K.; RAVISHANKAR, S. A comparison of the antimicrobial activity of garlic, ginger, carrot and turmeric pastes against Escherichia coli $\mathrm{O} 157: \mathrm{H7}$ in laboratory buffer and ground beef. Foodborne Pathogens and Disease, Larchmont, v. 2, n. 4, p. 330-340, 2005. 
GUPTA, S. K.; SHARMA, A. Medicinal properties of Zingiber officinale Roscoe - Aa review. Journal of Pharmacy and Biological Sciences, Ghaziabad, v. 9, n. 5, p. 124-129, 2014.

HALLIWELL, B.; AESCHBACH, R.; LOLIGER, J.; ARUOMA, O. I. The characterization on antioxidants. Food and Chemical Toxicology, Oxford, v. 33, n. 7, p. 601-617, 1995.

HAMINIUK, C. W. I.; PLATA-OVIEDO, M. S. V.; GUEDES, A. R.; STAFUSSA, A. P.; BONA, E.; CARPES, S. T. Chemical, antioxidant and antibacterial study of Brazilian fruits. International Journal of Food Science \& Technology, Osney Mead, v. 46, n. 7, p. 15291537, 2011.

HAMINIUK, C. W. I.; PLATA-OVIEDO, M. S. V.; MATOS, G. de; CARPES, S. T.; BRANCO, I. G. Extraction and quantification of phenolic acids and flavonols from Eugenia pyriformis using different solvents. Journal of Food Science and Technology, Osney Mead, v. 51, n. 10, p. 2023-2044, 2012.

HARTANTI, D.; IRIANI, N. O.; HAMAD, A. Natural preservation of fresh chicken meats utilizing combination of essential oils of clove and ginger. In: UMP-PIC \& ISCC, 2., 8., 2017, Purwokerto Proceeding... Purwokerto: Universitas Muhammadiyah Purwokerto, 2017. p. 75-83.

HASAN, H. A.; RAAUF, A. M. R.; RAZIK, B. M. A.; HASSAN, A. R. Chemical composition and antimicrobial activity of the crude extracts isolated from Zingiber officinale by different solvents. Pharmaceut Anal Acta, New Haven, v. 3, n. 9, p. 1-5, 2012.

HUTCHISON, J. E. Greener nanoscience: a proactive approach to advancing applications and reducing implications of nanotechonology. American Chemical Society Nano, Washington, v. 23, n. 3, p. 395-402, 2008.

IORA, S. R. F.; MACIEL, G. M.; ZIELINSKI, A. A. F.; SILVA, M. V. da; PONTES, P. V. de A.; HAMINIUK, C. W. I.; GRANATO, D. Evaluation of the bioactive compounds the antioxidant capacity of grape pomace. Food Science \& Technology, London, v. 64, n. 50, p. 6269, 2015.

KATEREGGA, J. N.; NANTALE, P. N.; NDUKUI, J. G. Rhizome of Zingiber officinale: possible source of alternative remedy for strep throat. Journal of Pharmaceutical and Scientific Innovation, Rampur, v. 2, n. 5, p. 51-54, out. 2013.

KAUSHIK, P.; GOYAL, P. Evaluation of various crude extracts Zingiber officinale rhizome for potential antibaterial activity: a study in vitro. Advances in Microbiology, Irvine, v. 1, n. 1, p. 7-12, 2011.
KOBAYASHI, K. D.; MCEWEN, J.; KAUFMAN, A. J. Ornamental ginger, red and pink. Ornamentals and Flowers, Honolulu, v. 37, p. 1-8, 2007.

KOCHUTHRESSIA, K. P.; BRITTO, S. J.; JASEENTHA, M. O.; RAJ, L. J. M.; SENTHIKUMAR, S. R. Antimicrobial efficacy of extracts from Alpinia purpurata (Vieill.) K. Schum. Against human pathogenic bacteria and fungi. Agriculture and Biology Journal of North America, Milford, v. 1, n. 6, p. 1249-1252, 2010.

KONA, L. A.; THOFEEQ, M. D.; VENKATA, R. In vitro studies and antibacterial activity of Alpinia purpurata. Austin Journal of Biotechnology \& Bioengineering, Telangana, v. 2, n. 4, p. 1-2, dez. 2015.

LIMSUWAN, S.; VORAVUTHIKUNCHAI, S. P. Bactericidal, bacteriolytic, and antibacterial virulence activities of Boesenbergia pandurata (Roxb) schltr extract against Streptococcus pyogenes. Tropical Journal of Pharmaceutical Research, Benin City, v. 12, n. 6, p. 1023-1028, 2013.

LIU, Q.; MENG, X.; LI, Y.; ZHAO, C.-N.; TANG, G.-Y.; LI, H.-B. Antibacterial and antifungal activities of spices. International Journal of Molecular Sciences, Guangzhou v. 18, n. 6, p. 2-62, 2017.

MAJHENIC, L.; SKERGET, M.; KNEZ, Z. Antioxidant and antimicrobial activity of guarana seed extracts. Food Chemistry, Barking, v. 104, n. 3, p. 1258-1268, 2007.

MOSTAFA, A. A.; AL-ASKAR, A. A.; ALMAARY, K. S.; DAWOUD, T. M.; SHOLKAMY, E. N.; BAKRI, M. M. Antimicrobial activity of some plant extracts against bacterial strains causing food poisoning diseases. Saudi Journal of Biological Sciences, Riyadh v. 25, n. 2, p. 361366, 2018

NEGI, P. S. Plant extracts for the control of bacterial growth: efficacy, stability and safety issues for food application. International Journal of Food Microbiology, Amsterdam, v. 156, n. 1, p. 1-17, 2012.

OONMETTA-AREE, J.; TOMOKO, S.; GRIANGSAK, G. Antimicrobial properties and action of Galangal (Alpinia galanga Linn.) on Sthaphylococcus aureus. Food Science + Technology, Londres, v. 39, n. 10, p. 1214-1220, 2006.

PATTARATANAWADEE, E.; RACHATANAPUN, C.; WANCHAITANAWONG, P.; MAHAKARNCHANAKUL, W. Antimicrobial activity of spice extracts against pathogenic and spoilage microorganisms. Kasetsart Journal, Bangken, v. 40, p. 159-165, 2006.

PERALTA, R. M.; OLIVEIRA, A. L.; ELER, G. J.; SOARES, A. A.; BRACHT, A. Functional properties 
of edible and medicinal mushrooms. Current Trends Microbiology, Trivandrum, v. 4, p. 45-60, 2008.

POELOENGAN, M. The effect red ginger (Zingiber officinale Roscoe) extract on the growth of mastitis causing bacterial isolates. African Journal of Microbiology Research, Lagos, v. 5, n. 4, p. 382-389, 2011.

RACHANA, S.; VENUGOPALAN, P. Antioxidant and bactericidal activity of wild turmeric extracts. Journal of Pharmacognosy and Phytochemistry, New Delhi, v. 2, n. 6, p. 89-94, 2014.

RAHMANI, A. H.; SHABRMI, F. M. Al.; ALY, S. M. Active ingredients of ginger as potencial candidates in the prevention and treatment of diseases via modulation of biological activities. International Journal Pathophysiolol Pharmacol, Faisalābād, v. 6, n. 2, p. 125136, 2014.

RAJ, C. A.; DOMINIC, S.; RAGAVENDRAN, P.; STARLIN, T.; RATHI, M. A.; GOPALAKRISHAN, V. K. Leaf extract of Alpinia purpurata (Vieill) K. Schum screened for its phytochemical constituents and antibacterial and anticancer activities. Journal of Chinese Integrative Medicine, Beijing, v. 10, n. 12, p. 1460-1464, 2012.

RAJSEKHAR, S.; KULDEEP, B.; CHANDAKER, A.; UPMANYU, N. Spices as antimicrobial agents: a review. International Research Journal of Pharmacy, Rampur, v. 3, n. 2, p. 4-9, 2012.

RIBEIRO, L. F.; RIBANI, R. H.; FRANCISCO, T. M. G.; SOARES, A. A.; PONTAROLO, R.; HAMINIUK, C. W. I. Profile of bioactive compounds from grape pomace (Vitis vinifera and Vitis labrusca) by spectrophotometric, chromatographic and spectral analyses. Journal of Chromatography B, Amsterdam, v. 15 p. 72-80, 2015.

ROMANIUK, J. A. H.; CEGELSKI, L. Bacterial cell wall composition and the of antibiotics by cell-wall and whole-cell NMR. Philosophical Transactions of the Royal Society of London. Series B, Biological Sciences, London, v. 5, n. 370, p. 1-14, 2015.

SAAD, R.; WAI, L.; HANIF, N.; YSUF, H. E.; ASMANI, F. Comparative studies of Zingiber officinale leaves and rhizomes on the antibacterial effect. International Journal of Pharmacy and Analytical Research, Żurawia, v. 3, n. 3, p. 262-268, 2014.

SAHOO, S.; SINGHI, S.; NAYAK, S. Chemical composition, antioxidant and antimicrobial activity of essential oil and extract of Alpinia malaccensis Roscoe (Zingiberaceae). International Journal of Pharmacy and Pharmaceutical Sciences, Madhya Pradesh, v. 6, n. 7, p. 183-188, 2014.
SHAREEF, H. K.; MUHAMMED, H. J.; HUSSEIN, H. M.; HAMEED, I. H. Antibacterial effecdt of ginger Zingiber officinale roscoe and bioactive chemical analysis using gas chromatography mass spectrum. Oriental Journal of Chemistry, Bhopal, v. 32, n. 2, p. 817-837, 2016.

SHARIFI-RAD, M.; VARONI, E. M.; SALEHI, B.; SHARIFI-RAD, J.; MATTHEWS, K. R.; AYATOLLAHI, S. A.; KOBARFARD, F.; IBRAHIM, S. A.; MNAYER, D.; ZAKARIA, Z. A.; SHARIFI-RAD, M.; YOUSAF, Z.; IRITI, M.; BASILE, A.; RIGANO, D. Plants of the genus Zingiber as a source of bioactive phytochemicals: from tradition to fharmacy. Molecules, Naples, v. 22, n. 2145, p. 1-20, 2017.

SILHAVY, T. J.; KAHNE, D.; WALKER, S. The bacterial envelope. Could Spring Harbor Perpectives in Biology, Woodbury, v. 2, n. 5, p. 1-16, 2010.

SILVA, N. C. C.; FERNANDES JÚNIOR, A. Biological properties of medicinal plants: a review of their antimicrobial activity. The Journal of Venomous Animals and Toxinas including Tropical Diseases, Botucatu, v. 13, n. 3, p. 402-413, 2010.

SOARES A. A.; SÁ-NAKANISHI, A. B.; BRACHT, A.; GOMES da COSTA, S. M.; KOEHNLEIN, E. A.; MARQUES de SOUZA, C. G.; PERALTA, R. M. Hepatoprotective effects of mushrooms. Molecules, Basileia, v. 1, n. 18, p. 7609-7630, 2013.

SOARES, S. E. Phenolic acids as antioxidants. Revista de Nutrição, Campinas, v. 15, n. 1, p. 71-81, 2002.

SOUZA, V. C.; LORENZI, H. Botânica sistemática: guia ilustrado para identificação das famílias de Angiospermas da flora brasileira, baseado em APG II. São Paulo: Nova Odessa, Instituto Plantarum, 2005. 640 p.

SPINELLA, M. The psychopharmacology of herbal medications: plants drugs that atler mind, brain and behavior. Alberta: MIT Press LTd, 2001. 590 p.

STOILOVA, I.; KRASTANOV, A.; STOYANOVA, A.; DENEV, P.; GARGOVA, S. Antioxidant activity of a ginger extract (Zingiber officinale). Food Chemistry, Barking, v. 102, n. 3 p. 764-770, 2007.

SUHAD, A.; AHMED, I.; JABBAR, A.; HAMSSAH, E. Study the antibacterial activity of Zingiber officinale roots against some of pathogenic bacteria. Al-Mustansiriya Journal Sci, Bagdá, v. 23, n. 3, p. 63-70, 2012.

SUBRAMANIAN, V.; SUJA, S. Phytochemical screening of Alpinia purpurata (Vieill). Research Journal of Pharmaceutical, Biological and Chemical Sciences, Tamilnadu, v. 2, n. 3, p. 866-871, 2011. 
TAIZ, L.; ZEIGER, E. Plant physiology. $3^{\text {th }}$ ed. Sunderland: Sinauer Associates, 2003. 690 p.

TAJKARIMI, M. M.; IBRAHIM, S. A.; CLIVER, D. O. Antimicrobial herb and spice compounds in food. Food Control, Kidlington, v. 21, n. 9, p. 1199-1218, 2010.

TEJADA, G. M.; SANCHEZ-GOMEZ, S.; KOWALSKI, I.; KACONIS, Y.; ANDRA, J.; SCHURHOLZ, T.; HORNEF, M.; DUPONT, A.; GARIDEL, P.; GUTSMAN, T.; DAVID, S. A.; BRANDENBURG, K. Bacterial cell wall compounds as promising targets of antimicrobial agents I. Antimicrobial peptides and lipopolyamines. Current Drug Targets, Hilversum, v. 13, n. 9, p. 1211130, ago. 2013.

UDOMTHANADECH, K.; VAJRODAYA, S.; PAISOOKSANTIVATANA, Y. Antibacterial properties of the extracts from some zingibereous species in thailand against bacteria causing diarrhea and food poisoning in human. International Transaction Journal of Engineering Management \& Applied Sciences \& Technologies, Penang, v. 6, n. 5, p. 203-213, 2015.

VENKATESH, R.; VIDYA, R.; KUMAR, S. S.; ANBARASAN, N. Evaluation of antibacterial activity of silver nanoparticles produced by Alpinia purpurata (Vieill) K. Schum. International Journal of Biosciences and Nanosciences, New Delhi, v. 1, n. 3, p. 68-76, 2014.
VICTÓRIO, C. P. Therapeutic value of the genus Alpinia Zingiberaceae. Brazilian Journal of Pharmacognosy, São Paulo, v. 21, n. 1, p. 194-201, 2011.

VILLAFLORES, O. B.; MACABEO, A. P. G.; GEHLE, D.; KROHN, K.; FRANZBLAU, S. G.; AGUINALDO, A. M. Phytoconstituints from Alpinia purpurata and their in vitro inhibitory activity against Mycobacterium tuberculosis. Pharmacognosy Magazine, Bangalore, v. 6, n. 24, p. 339-344, 2010.

VORAVUTHIKUNCHAI, S. P. Family Zingiberaceae compounds as functional antimicrobials, antioxidants, and antiradicals. Food, Kagawa, v. 1, n. 2, p. 227-240, 2007.

WHITE, B. Antimicrobial activity of ginger against different microorganisms. Physician, Mashhad, v. 75, p. 1681-1691, 2007.

WONG, L. F.; LIM, Y. Y.; OMAR, M. Antioxidant and antimicrobial activities of some Alpinia species. Journal of Food Biochemistry, Westport, v. 33, n. 6, p. 835-851, 2009.

ZAINAL-ABIDIN, Z.; ABDUL-WAHAB， N. A.; GHAZI-AHMAD, M. K.; MOHD-SAID, S. In vitro antibacterial activity of Zingiber officinale snd Orthosiphon stamineus on Enterococcus faecalis. Journal of Agricultural Science, Malaysia, v. 19, n. 13, p. 112-121, 2017. 
